\title{
Rational Structural Fire Engineering Design, Based on Simulated Real Fire Exposure
}

\section{OVE PETTERSSON}

Department of Fire Safety Engineering

Lund Institute of Technology, Lund University

Box 118, S-221 00 Lund, Sweden

\begin{abstract}
As a result of the powerfully increased international fire research during the last decades, more and more components and systems within fire safety engineering are becoming amenable to analytical and computer modelling. The most manifest verification of this development probably holds for the fire engineering design of load bearing and separating structures.

The paper begins with a general survey on the characteristics of a reliability based structural fire engineering design. Then, the physical model, describing the simulated real fire exposure and the thermal and mechanical behaviour of the structure, is commented on with regard to the present state of knowledge and the need of further research. Finally, the different uncertainty sources in the design process and the principles of a cost-benefit optimization are dealt with and exemplified.
\end{abstract}

KEYWORDS: reliability based design, load bearing structures, real fire exposure, thermal behaviour, mechanical behaviour, sensitivity analysis

\section{INTRODUCTION}

In a general sense, a fire engineering design of a building and its components is a nondeterministic process. Some level of risk - the probability of adverse events - is virtually unavoidable and we have to recognize the impossibility of absolute compliance with preset goals. The performance of the object at fire has to be described and measured in probabilistic terms.

This is a fundamental perspective from which we have to evaluate and judge the building fire safety code systems now in force. Historically, they were written without actually stating their objective safety level and, still less, without any analytical measurement of the objectives involved. Consequently, there is an urgent need for future attempts to evaluate the levels of safety inherent in present local and national fire protection regulations. 
Lack of knowledge with respect to analytical models describing the physical processes of design components and systems has for a long time prevented efforts to quantatively assess risk levels. However, as a result of the powerfully increased extent of the international fire research during the last decades, more and more components and systems are now becoming amenable to analytical and computer modelling. Considerable progress than has been made concerning such phenomena and procedures as:

* The reaction to fire of materials,

* the fire growth in a compartment,

* the fully developed compartment fire,

* the fire spread between buildings,

* the fire behaviour of load bearing and separating building structures,

* the smoke filling in enclosures and smoke movement in escape routes and multistorey buildings,

* the interaction of sprinklers and fire, including sprinkler and fire venting interaction,

* the process of escape, and

* the systems approach to the overall fire safety of a building, in its most general form comprising fire development models interacting with human response models.

As a consequence of this progress, a fundamental development goes on in the field of codes, specifications, and recommendations for fire engineering design in a broad sense. Some characteristic trends in this development are:

* An improved connection to real fire scenarios,

* an increasing extent of design, based on functional requirements and performance criteria,

* a development of new test methods, which are, as far as possible, material independent and related to well-defined phenomena and properties,

* an increasing application of analytical design - reliability based in its most qualified form,

* an extended use of integrated assessments, and

* an introduction of goal-oriented systems of analysis of the total, active and passive fire protection for a building.

The most manifest verification of these development trends probably relates to the fire engineering design of load bearing and separating structures. An analytical determination of the fire resistance of structural elements is successively being approved by the authorities in more and more countries as an alternative to the internationally predominant design, based on the results of the standard fire resistance test and connected classification. The further step to permit a general practical application of an analytical design, based on a natural compartment fire concept, was taken by the Swedish authorities as early as in 1967 and later also a few other countries have officially opened this possibility of structural fire design. The significant contributions by the Fire Commission of the Conseil International du Bâtiment, CIB W14, in the form of a state-of-art report, presenting in 1983 a conceptual approach towards a probability based design guide on structural fire safety [1], supplemented in 1986 by a model code/design guide [2], then constitutes an important aid in drafting corresponding national regulations and recommendations. For the European countries, the recently finalized EUROCODE drafts, to be issued as European Prestandards and supplemented with national application documents, certainly will contribute to an essentially increased practical use of analytical structural fire design methods. A draw-back then is, that the material related codes very strongly focus on the fire design, based on the thermal exposure according to the standard fire resistance test, but the general code, specifying the basis of design and mechanical and thermal actions on fire exposed structures, also gives some guidance, in the form of informative annexes regarding the alternate structural fire design, based on a parametric fire 
exposure determined by fire models and on the specific physical parameters describing the conditions in the fire compartment.

An analytical fire engineering design can now be performed for most cases, as concerns steel structures. Validated material models for the mechanical behaviour of concrete under transient high-temperature conditions [3-5] and thermal models for a calculation of the charring rate in wood exposed to fire [6-8], derived during the last decades, have significantly enlarged the area of practical application of an analytical structural fire design. To support this application, design diagrams and tables have been computed and published, giving directly, on the one hand, the temperature state of the fire exposed structure, and on the other, a further transfer to the corresponding load bearing capacity of the structure - cf., for instance, [9-39].

In the following, first a general survey is presented on the characteristics of a reliability based structural fire engineering design. Then, the appurtenant deterministic model, describing the fire exposure and the inherent physical processes of the thermal and mechanical behaviour of the structure, is commented on with regard to the present state of knowledge and the need of further research. Finally, the different uncertainty sources in the design process and the principles of a cost-benefit optimization are mentioned and exemplified.

\section{CHARACTERISTICS OF A RELIABILITY BASED STRUCTURAL FIRE ENGINEE- RING DESIGN}

Essential components of a rational design methodology include, in the ideal case $[40,41]$

* analytical modelling of relevant processes; verification of validation and accuracy; determination of critical design parameters,

* formulation of functional requirements, independent of choice of design process and expressed either in deterministic or probabilistic terms,

* determination of design parameter values, and

* verification by reliability analysis that the choice of safety factors leads to safety levels which are consistent with the expressed functional requirements.

For the probabilistic model to be integrated with the analytical model(s) of the relevant processes, the following levels can be distinguished:

* An exact evaluation of the failure probability, using multi-dimensional integration or Monte Carlo simulation,

* an approximate evaluation of the failure probability, based on First Order Reliability Methods (FORM), and

* a practical design format calculation, based on partial safety factors and taking into account characteristic values for action effects and response capacities.

For practical purposes, an exact evaluation of the failure probability is not feasible. Also, the FORM approximations are too cumbersome for every day design but may be applied in special cases. For normal design, the practical design formats have to be used.

The procedure for a reliability based structural fire engineering design related to a FORM approximation and a practical design format calculation is illustrated by flow diagrams in Figures $I$ and 2 , respectively. For generality, the procedure is demonstrated for a load bearing structure of charring material, for instance, a timber structure [31, 42]. 


\section{Structural Fire Engineering Design Based on FORM Approximation}

Following the flow diagram in Figure 1 for a structural fire engineering design, based on a FORM approximation, the characteristics of the fire load and fire compartment constitute the basis for the determination of the fire exposure, expressed by the gas temperature or the heat flow to the structure as a function of time and either computed by solving the energy and mass balance equations of the compartment fire or chosen from some systematized design basis.

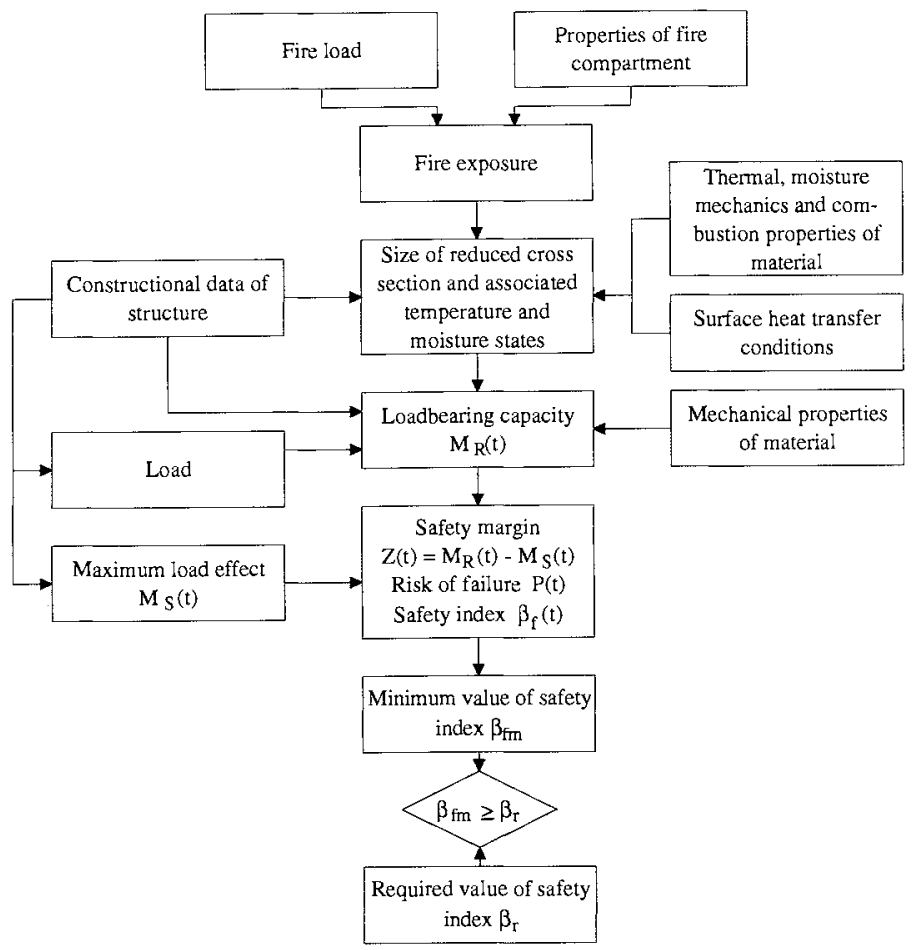

FIGURE 1. Structural fire engineering design, based on first order reliability method (FORM).

Together with constructional data of the structure and information on the thermal, moisture mechanics and combustion properties of the structural material at elevated temperatures, the fire exposure gives the reduced cross section of the structure and the associated transient temperature and moisture conditions. With the mechanical properties of the structural material as further input data, the transient temperature and moisture state for the uncharred part of the cross section then has to be transferred to the time variation of the load bearing capacity of the structure during the fire exposure, expressed, for instance, as the bending moment $M_{R}(t)$ in a decisive section. The load, statistically representative for the fire situation, gives a maximum load effect with a bending moment $M_{S}(t)$ in the section for the load bearing capacity $M_{R}(t)$.

The quantities $M_{R}(t)$ and $M_{S}(t)$ define the safety margin $Z(t)$ as 


$$
Z(t)=M_{R}(t)-M_{S}(t)
$$

The related failure probability $P(t)$ and the safety index $\beta_{f}(t)$, defined as the quotient between the average safety margin and the standard deviation, then can be calculated by the formulae:

$$
\begin{aligned}
& P(t)=\int_{-\infty}^{0} f_{Z}[Z(t)] d Z \\
& \beta_{f}(t)=\phi^{-1}[1-P(t)]
\end{aligned}
$$

where $f_{Z}[Z(t)]$ is the probability density function of the safety margin $Z(t)$ and $\Phi^{-1}$ the inverse of the standardized normal distribution.

The design criterion implies that the minimum value of the safety index for the structure during the relevant fire exposure $\beta_{\mathrm{fm}}=\min \left\{\beta_{\mathrm{f}}(\mathrm{t})\right\}$ shall meet the required value of the safety index $\beta_{\mathrm{r}}$, i.e.

$$
\beta_{\text {fm }}-\beta_{\mathrm{r}} \geq 0
$$

At the determination of the safety margin $Z(t)$, the failure probability $\mathbf{P}(\mathrm{t})$, and the safety index $\beta_{\mathrm{f}}(t)$, the following probabilistic effects have to be taken into account:

* The uncertainty in specifying the loading and of the model for calculating the load effect on the structure,

* the uncertainty in specifying the fire load and the characteristics of the fire compartment,

* the uncertainty in specifying the design data of the structure and the thermal, moisture mechanics, combustion, and mechanical properties of the structural material, and

* the uncertainty of the analytical models for the calculation of the compartment fire and the related heat transfer to the structure, the size of reduced cross section and the associated temperature and moisture states, and the load bearing capacity of the structure.

The required value of the safety index $\beta_{\mathrm{r}}$ depends on the probability of occurence of a fully developed compartment fire $p_{1}$, the reduction of this probability due to fire-fighting by the fire brigade $p_{2}$ and to the effect of an installed fire extinguishment system $p_{3}$, if any, and the consequences of a structural failure. For the detailed technique of deriving required values of the safety index $\beta_{\mathrm{r}}$, see, for instance $[1,2,43,44]$. Example values of $\mathrm{p}_{1}, \mathrm{p}_{2}$ and $\mathrm{p}_{3}$ are given in $[1,2,45]$.

\section{Structural Fire Engineering Design Based on Practical Design Format}

As mentioned, for normal applications of a reliability based structural fire engineering design the practical design format has to be used and the flow diagram in Figure 2 illustrates the procedure for such a design.

For a load bearing structure, the design format condition implies that the design minimum value of the load bearing capacity $R_{d}(t)$ during the fire exposure shall meet the design load effect on the structure $S_{d}$, i.e. 


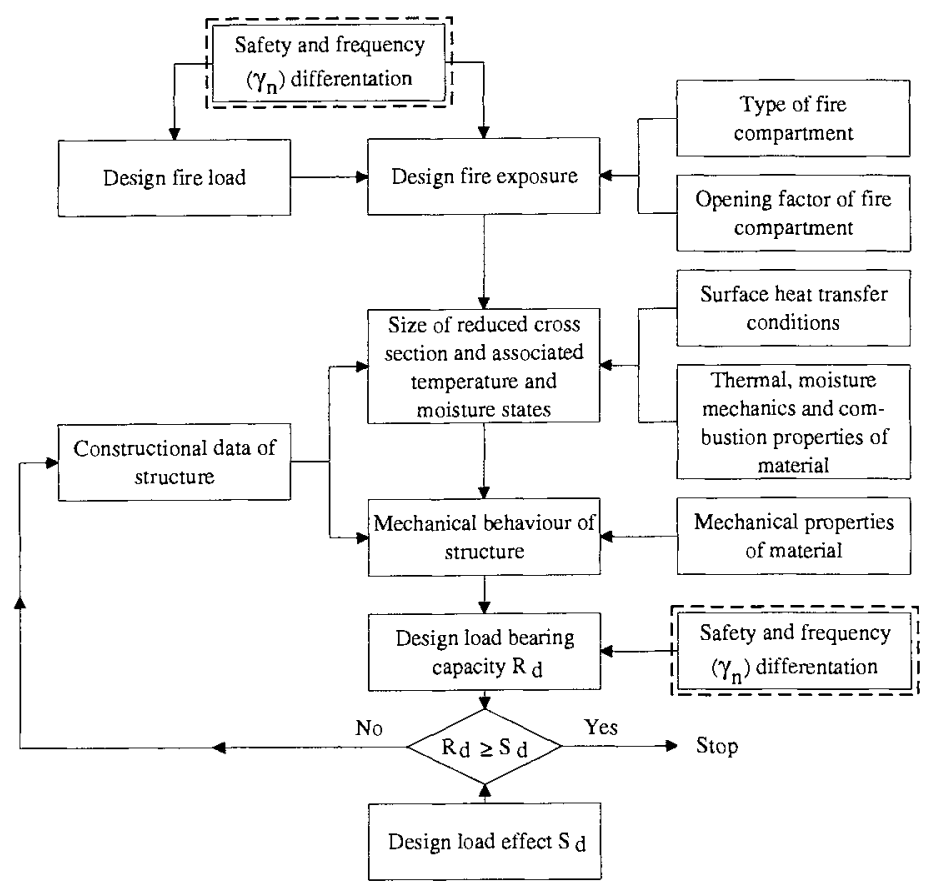

FIGURE 2. Structural fire engineering design, based on partial safety factors (practical design format).

$$
\mathbf{R}_{\mathrm{d}}=\min \left\{\mathbf{R}_{\mathrm{d}}(\mathrm{t})\right\} \geq \mathbf{S}_{\mathrm{d}}
$$

The condition must be fulfilled for all relevant types of failure. For a separating structure, the design format condition comprises requirements with respect to insulation and integrity. The insulation condition then implies that the design maximum value of the temperature on the unexposed side of the structure $T_{s d}(t)$ during the fire exposure shall meet the temperature $T_{c r}$ acceptable with respect to the requirement to prevent a fire spread from the fire compartment to an adjacent compartment, i.e.

$$
\mathrm{T}_{\mathrm{sd}}=\max \left\{\mathrm{T}_{\mathrm{sd}}(\mathrm{t})\right\} \leq \mathrm{T}_{\mathrm{cr}}
$$

For the integrity requirement, there is no analytically expressed design format condition available. Consequently, this condition has to be proved experimentally, when decisive.

In the practical design format, the probabilistic influences are considered by specifying characteristic values, expressed as a specified fractile, and related partial safety factors for the fire load, such structural design data as imperfections, the thermal material properties, the mechanical material properties and the loading. In deriving the partial safety factors, all uncertainties listed above in connection with the presentation of the design based on FORM approximations have to be included. 
The functional requirements, specified for the design should be differentiated with respect to type of occupancy, type and size of building, number of floors, size and location of fire compartment, and the importance of the structure or structural element to the overall stability of the building. This may be considered by a system of safety classes associated with different failure probabilities, the probability of the occurence of a fully developed compartment fire included. In design verification, this safety differentiation is accounted for by applying different partial safety factors for different safety classes or by applying corresponding safety differentiation factors $\gamma_{\mathrm{n} 1}$.

For a certain occupancy, provisions employed for reducing the frequency of a fully developed fire for a particular project, i.e.

* available force of fire brigades, and

* approved alarm and sprinkler systems

should be considered. In design verification, this frequency differentiation is accounted for by applying different partial safety factors, depending on employed provisions and fire compartment size, or by applying corresponding frequency differentiation factors $\gamma_{n 2}$.

Summing up, the design format condition to be verified for a load bearing structure reads:

$$
\begin{aligned}
& R_{d n}=\frac{1}{\gamma_{n}} R_{d}\left(R_{d 1}, R_{d 2}, \ldots\right) \geq S_{d}\left(G_{d}, Q_{d 1}, \ldots\right) \\
& \text { or } \\
& \frac{1}{\gamma_{n}} R_{d}\left(R_{k 1} / \gamma_{r 1}, R_{k d} / \gamma_{r 2}, \ldots\right) \geq S_{d}\left(G_{k}, \Psi_{i}, Q_{k, i}, Q_{k, i n d}\right)
\end{aligned}
$$

where

$R_{d}$ is the design value of the ultimate load bearing capacity, determined by its lowest value during the relevant fire exposure,

$R_{\mathrm{di}}, R_{\mathrm{ki}}, \gamma_{\mathrm{ri}}$ are design values, characteristic values and partial safety factors, respectively, related to the ultimate load bearing capacity and accounting for the uncertainties in heat exposure and thermal and mechanical response, cf. Figure 2,

$S_{d}$ is the design load effect at fire, determined by considering an accidental load combination of the form

$$
G_{k}+\sum_{i} \Psi_{i} Q_{k, i}+Q_{k, i n d}
$$

where all actions - permanent loads (actions) $G_{k}$, variable loads (actions) $Q_{k, i}$ and indirect actions due to fire exposure $Q_{k \text {, ind }}$ - are given by their characteristic values, $\psi_{i}$ are combination coefficients, generally different for $i=1$ and $i>1$, and all other load factors are set to unity $[2,46]$,

$\gamma_{\mathrm{n}}=\gamma_{\mathrm{n} 1} \gamma_{\mathrm{n} 2}$ is a safety and frequency differentiation factor, accounting for different safety classes $\left(\gamma_{n 1}\right)$ and active fire protection measures $\left(\gamma_{n 2}\right)$ according to above.

In Eq. (7), the safety and frequency differentiation factor $\gamma_{n}$ has been allocated to the design load bearing capacity $R_{d}$. Alternatively, $\gamma_{n}$ may be applied as to affect the design fire load thus modifying the design fire exposure, as shown in Figure 2.

Methods for the determination of values of the partial safety factors $\gamma_{\mathrm{ri}}$ and the safety and frequency differentiation factor $\gamma_{n}$ are presented in $[1,2]$, in which also example values of the factors are given. Factor values for practical design are also specified in the EUROCODE 
drafts, now being issued as European Prestandards [46-50], and in [36].

\section{MAIN COMPONENTS OF STRUCTURAL FIRE ENGINEERING DESIGN}

The flow diagrams in Figures 1 and 2 for a rational fire engineering design of load bearing structures identify three main components, viz.

* the design fire exposure,

* the thermal material properties and the transient temperature state, and

* the mechanical material properties and the structural behaviour.

In the following, these components are briefly commented on with regard to the present state of knowledge and the need of further research.

\section{Design Fire Exposure}

The fully developed compartment fire, which is the decisive part of a fire for the thermal and mechanical behaviour of load bearing and separating structures in buildings, has been subjected to comprehensive studies for a very long time and during the past 30 years several analytical models, simulating real fires, have been presented. In a review paper [51], published 10 years ago, 14 such models were classified on the basis of 14 principal modelling aspects. The models included then either represent important steps in the evolution of knowledge or offer unique concepts.

The fundamental characteristics for a complete description of the fully developed compartment fire are the time variations of the

(1) rate of heat release, RHR,

(2) gas temperature,

(3) geometrical and thermal data for external flames,

(4) smoke and its optical properties, and

(5) composition of the combustion products, particularly toxic and corrosive gases.

The simulation models, developed for structural fire purposes, then concentrate on the characteristics (1) to (3). Most models are partly theoretically and partly empirically based with the empirical part focusing on data on the rate at which the fuel is consumed.

For known combustion characteristics of the fire load, the time curve of the gas temperature in the fire compartment or the flux to an exposed structure can be calculated in the individual practical application from the energy and mass balance equations of the compartment fire [5265]. The practical use of these equations requires access to well-documented computer programs and there are basically three such computer codes available which are adapted for engineering applications, viz. SFIRE [54, 62], COMPF-2 [58] and BRAND [59]. A closedform approximation, arranged to suit hand calculations, is presented in [60].

If reasonably correct input data are used, the computer programs quoted have the ability to simulate real fires with practically acceptable accuracy in compartments of moderate size, i.e. compartments with a size representative of dwellings, ordinary offices, schools, hospitals, hotels and libraries. For these types of applications, systematized design bases are available, derived by the computer programs and essentially facilitating a fire engineering design of load 
bearing and separating structures. The internationally most frequently referred design basis then is the set of gas temperature-time curves as a function of the fire load, opening factor of the compartment and the thermal properties of the structures enclosing the compartment, which originates from early contributions by Magnusson-Thelandersson [54]. The design basis was computed under the simplifying assumptions that

* the combustion of the fire load takes place entirely within the fire compartment,

* the fire process is ventilation controlled, and

* the gas temperature is uniform wihtin the fire compartment at any time,

giving a conservative solution. The design basis has been officially approved by the Swedish authorities for practical application since 1976 [66] and is also included, as informative, in EUROCODE 1 [46], but in a parametric form according to [63]. EUROCODE 1 also includes, as informative, a simplified method for the calculation of the thermal exposure on external structural members from flames emerging from window openings, based on $[67,68]$.
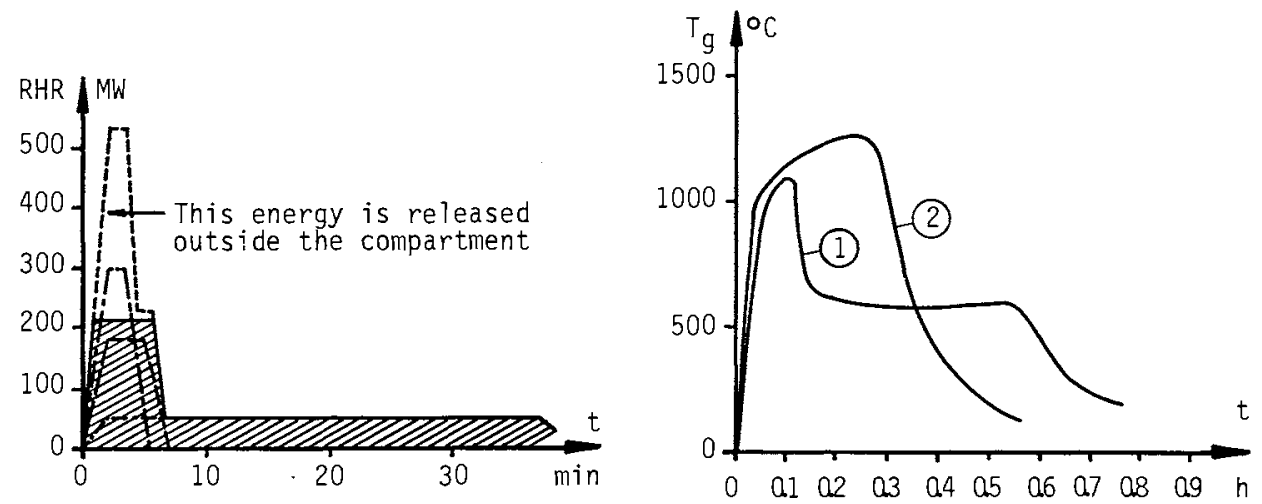

FIGURE 3. Gas temperature-time curves, $T_{g}-t$, based on actual rate of heat released inside the fire compartment [curve (1)] and on the conservative assumption that all energy is released inside the compartment [curve (2)], respectively. The figure to the left shows rate of heat release, RHR, versus time for the various combustible items and the cumulative curves: -...paper, - - - furniture, - - - floor covering, - - - total RHR of fire load, — RHR, released inside compartment. Fully developed compartment fire in an office space.

A main problem in applying the computer programs mentioned in a more accurate way in the design is the incomplete information available on the rate of heat release due to the combustion of the fire load. Such information is, however, continuously being improved and during the last ten years relevant data have been determined on such fire load components as upholstered furniture, solid furniture with flat extended surfaces, mattresses and beds, combustible lining materials, and paper stored in desks, filing cabinets or on shelves. A survey of such data is given in [62].

The importance of correct input data is exemplified in Figure 3 which shows calculated gas temperature-time curves for a specified fire load and compartment [62]. Curve (1) then gives the gas temperature, computed with regard taken to that only a part of the energy content of the fire load is released inside the compartment during the fire. Curve (2) shows the corresponding curve based on the conservative assumption that all the energy content of the fire load is released inside the compartment. 
For large compartments as, for instance, in industrial buildings and sports halls, the computer programs and the related simplified design basis referred to do not give a satisfactory simulation of the real fire exposure. For such applications, there are no simulation models of zone type available and the structural fire engineering design then has to be based on field models for the prediction of the fire exposure $[69,70]$.

\section{Thermal Material Properties and Transient Temperature State}

The transient heat flow within a fire exposed structure is governed by the Fourier heat balance equilibrium equation, having the density, thermal conductivity, and specific heat capacity or specific volumetric enthalpy as material properties. The solution of the Fourier equation is complicated by the fact that the thermal material properties depend on the temperature to an extent that cannot be disregarded. Further complications arise for moist materials and for materials with phase changes during the heating.

In ordinary design, the influence of moisture is considered in a simplified way in calculating the transient temperature state of fire exposed structures by assuming that all moisture evaporates, without any moisture transfer, at the temperature $100^{\circ} \mathrm{C}$ or within a narrow temperature range with the heat of evaporation giving a corresponding change in the enthalpytemperature curve. The influence of phase changes is included in a similar way.

In reality, the moisture distribution changes continuously in the structure during the fire exposure. Hence, in principle, it is not correct to include the effect of moisture content in the thermal properties. In a structure of moist material, the heat transfer is combined with a mass transfer and, from a strict thermodynamical point of view, these two transport mechanisms should be analysed simultaneously by a system of inter-related partial differential equations.

In $[7,71]$, an accurate model and a related computer program, WOOD2, is presented for the inter-related heat and mass transfer in fire exposed timber structures. The model simulates the transient temperature and moisture states in both uncharred and charred parts of the cross sections of the structure, as well as the growth of charred layer in combination with its oxidation at the surface due to variable thermal exposure. Output data from the calculations are the cross section profiles of temperature, moisture, pressure and density, and the penetration of the charcoal layer and mass loss as a function of time. Material properties required are the thermal conductivity, specific heat capacity, reaction rate and heat of reaction, surface reaction rate, permeability, and dynamic viscosity. A corresponding model for the inter-related heat and mass transfer in fire exposed concrete structures is presented in [72]. The models are experimentally validated.

For the practical determination of the transient temperature states of fire exposed structures, numerical methods have been developed and arranged for computer calculations. The methods are based either on finite difference or finite element approximations. For the first group of methods, reference can be given to $[20,37,73-76]$, and for the group using finite element methods $[20,77-82]$.

The computer programs can be used directly in a rational structural fire engineering design or as a tool for calculating diagrams and tables, facilitating a practical determination of the design temperature state for varying fire exposure and structural characteristics. For a simulated real fire exposure according to EUROCODE 1[46] and Swedish Building Code [66], 
such a design basis is given in $[10,11,15,22,24]$ for steel structures and in $[11,15,36]$ for concrete structures. Formulae and diagrams for a direct determination of the charring depth in timber structures for the same fire exposure are presented in $[6,34]$.

\section{Mechanical Material Properties and Structural Behaviour}

Fundamental parameters in available tests for the determination of the mechanical material properties at elevated temperatures are the heating process, application and control of load, and control of strain. Practically, the tests can be referred to different testing regimes as follows [83]:

* steady state tests, giving information on

- stress-strain relationship (stress rate control, $\dot{\sigma}=$ const),

- stress-strain relationship (strain rate control, $\dot{\varepsilon}=$ const),

- creep (stress control, $\sigma=$ const)

- relaxation (strain control, $\varepsilon=$ const),

* transient state tests, giving information on

- failure temperature, total deformation (stress control, $\sigma=$ const),

- restraint forces, total forces (strain control, $\varepsilon=$ const).

As the material properties measured depend on the test method used, it is necessary that the test results always are accompanied by an accurate specification of the test conditions applied.

A calculation of the mechanical behaviour and load bearing capacity of a fire exposed structure on the basis of the transient temperature state requires access to validated models for the mechanical behaviour of the structural materials involved within the relevant temperature range.

For steel, such models have been available for many years [83-87]. In the models, the total strain is divided into thermal strain, instantaneous stress-related strain, and creep strain. Some of the models operate with temperature-compensated time according to Dorn [84].

Analytical models for the determination of the mechanical behaviour and load bearing capacity of fire exposed steel beams, columns and frames are presented in, for instance, [20, 85-96], cf. also [37] in which further references are given. The most generally applicable models are those described in $[87,89-96]$, and examples of their ability to deal with multi-storey and high rise building frames are included in [94-96]. The computer program, put forward in [96], integrates the fire exposure simulation, comprising field modelling of open and enclosed pool and jet fires, the heat transfer simulation, and the simulation of the mechanical response of complex offshore structures. Simplified design bases, giving directly the load bearing capacity for a design temperature state or the critical temperature state for a design load effect, are presented in $[10,14,15,17,19,22,24,26,28,30,85]$.

For concrete, the mechanical behaviour at elevated temperatures is more complex than for steel. For stressed concrete under transient conditions, considerable deformations develop during the first heating which do not occur at steady state temperature conditions.

For practical design, the total strain $\varepsilon$ for fire exposed concrete, stressed in compression, can be assumed to follow the formula [3]: 
where $\varepsilon_{\text {th }}$ is thermal strain, including shrinkage, measured on unstressed specimens under variable temperature; $\varepsilon_{\sigma}$ instantaneous, stress related strain, based on stress-strain relations, obtained at a rapid rate of loading under constant, stabilized temperature; $\varepsilon_{\mathrm{cr}}$ creep strain or time dependent strain, measured under constant stress at constant, stabilized temperature; $\varepsilon_{\mathrm{tr}}$ transient strain accounting for the effect of temperature increase under stress, derived from

tests under constant stress and variable temperature; $\sigma, \tilde{\sigma}$ stress and stress history, respectively, and $\mathbf{t}=$ time.

Parameter formulations for each of the strain components are given in [3] as well as practical guidance on the application of the material behaviour model at a transient stress and temperature state. Normally, the transient strain $\varepsilon_{t r}$ is the predominant component.

A multiaxial constitutive model for concrete in the temperature range up to $800^{\circ} \mathrm{C}$ is formulated in [97]. The deformation behaviour is isotropic, elastic-viscoplastic-plastic in the compression region and brittle failure is assumed in the tensile region.

A comprehensive survey on the mechanical properties of concrete under high temperature exposure is given in [98].

Access to structure independent, functionally well-defined material behaviour models of the kind exemplified is a condition for validated predictivity of simulation models and related computer programs for the mechanical behaviour and load bearing capacity of fire exposed reinforced concrete structures and composite steel-concrete structures. Models and computer programs, more or less accurately fulfilling this condition, are presented in, for instance, [20, $27,92,93,99-104]$, dealing with beams, columns and frames. A computer program for evaluating the fire response of reinforced concrete slabs is published in [105]. Simplified methods, facilitating the practical determination of primarily the load bearing capacity, can be found in $[12-16,18,23,33,35,36,48,49,73,74,106]$.

The methods referred to - simplified as well as the more accurate - for a determination of the mechanical behaviour and load bearing capacity of fire exposed concrete structures do not include failures with respect to shear, bond and anchorage, and spalling.

For spalling its risk of occurrance can be roughly estimated by design diagrams, based on comprehensive experimental studies [107] or on theoretically derived failure criteria with the compressive stresses from the temperature gradient and the external loading, the tensile stress due to the vaporization and migration of moisture, and the tensile concrete strength as input data [108]. There are also early theoretical approaches for a principal description of the physical processes causing the spalling $[109,110]$. The important progress during the last years in modelling the heat and mass transfer in fire exposed structures $[7,71,72]$ has considerably improved the possibilities to develop a more complete and accurate theory of spalling and an improved related design basis.

For shear, and bond and anchorage, there are no validated calculation methods available for a structural fire design - cf. further [111], presenting the state of the art and the need of further research. In a practical design, it is therefore necessary to detail the structure in such a way 
that these types of failure will have a lower probability of occurance than the failures being dealt with properly in the design.

For fire exposed load bearing timber structures, the potential for an analytical modelling of the mechanical behaviour and load bearing capacity is more limited than for steel and concrete structures. Available information on the strength and deformation properties is mainly limited to results of tests with small specimens, conditioned to different combinations of temperature and moisture content [3, 112]. Furthermore, there are a few studies presented on the mechanical behaviour of wood at fire exposure conditions with a more general approach [113]. However, at present, there is no analytical model developed for the mechanical behaviour of wood describing the deformation process at simultaneous transient states of stress, temperature and moisture. This limits the structural fire design mainly to a determination of the ultimate load bearing capacity on the basis of simplified reduction factors $[15,31,34,39,42,50]$. A design method with respect to lateral buckling of fire exposed laminated wood beams is presented in [114].

\section{UNCERTAINTIES OF DESIGN COMPONENTS. COST-BENEFTT OPTIMIZATION}

The rapid progress in analytical and computer modelling of phenomena and processes of importance fof a fire engineering design stresses the need of internationally standardized procedures for evaluating the predictive capabilities of the models and for documenting the computer software. Two ASTM Standard Guides $[115,116]$ contribute essentially to this task.

An evaluation of the model capabilities is critical in establishing both the applicability and limitations of the models for a specific use. The process recommended in the Standard Guide [115]

* includes a brief description of the model and the scenario for which evaluation is sought,

* presents methodologies for conducting an analysis to quantify the sensitivity of model predictions to various uncertainty factors,

* provides several alternatives for evaluating the accuracy of the predicitons of the model, and

* gives guidance on the relevant documentation required to summarize the evaluation process.

A documentation of the computer software is necessary to ensure that users can judge the adequacy of the scientific and technical basis for the models, select the appropriate computer operating environment, and use the software effectively within the specified limitations. Adequate documentation also will help to prevent unintentional misuse of the computer software. The guidelines in [116] are presented in terms of three types of documentation: (1) technical document, (2) user's manual, and (3) installation, maintenance, and programming manual.

There are not very many sensitivity or uncertainty studies published of relevance for structural fire engineering design. The most comprehensive study is probably still the one presented by Magnusson twenty years ago $[24,41,117]$. The methodology developed for this study is quite general and applicable to a wide class of structures and structural elements. To get applicable and efficient final safety measures, the probabilistic analysis is numerically exemplified for an insulated, simply supported steel beam of I-cross section as a part of a floor or roof assembly. The chosen statistics of dead and live load and fire load are representative for office 
buildings.

With the basic data variables selected, the different uncertainty sources in the design procedure were identified and dissembled in such a way that available information from laboratory tests could be utilized in a manner as profitable as possible. The derivation of the total or system variance $\operatorname{Var}(R)$ in the load bearing capacity $R$ was divided into two main stages: variability $\operatorname{Var}\left(\mathrm{T}_{\max }\right)$ in maximal steel temperature $T_{\max }$ for a given type of structure and a given design fire compartment, and variability in strength theory and material properties for known value of $\mathrm{T}_{\max }$.

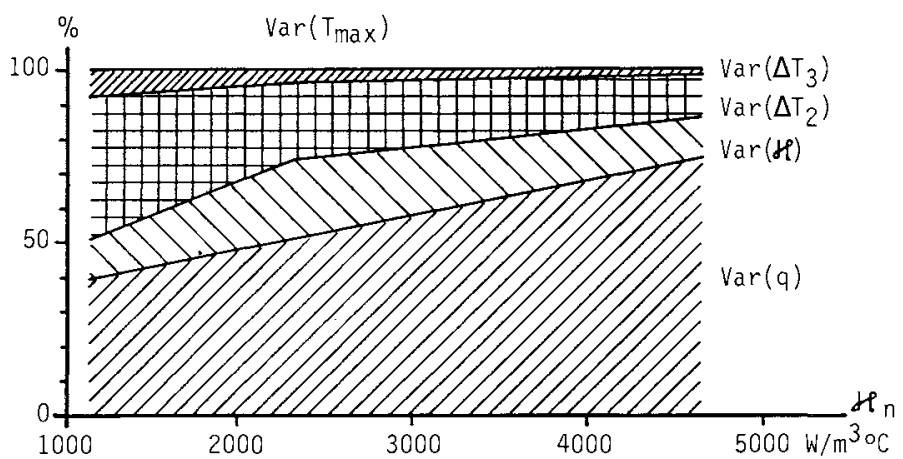

FIGURE 4. Separation of total variance in maximum steel temperature $T_{\max }$ into component variances as function of insulation parameter $\kappa_{\mathrm{n}}$.

The results obtained are exemplified in Figure 4, giving the decomposition of the total variance in maximum steel temperature $\mathrm{T}_{\max }$ into the component variances as a function of the insulation parameter $\kappa_{\mathrm{n}}=\mathrm{A}_{\mathrm{i}} \mathrm{k}_{\mathrm{i}} /\left(\mathrm{V}_{\mathrm{s}} \mathrm{d}_{\mathrm{i}}\right)$. $\hat{A}_{\mathrm{i}}$ is the interior surface area of the insulation per unit length, $d_{i}$ the thickness of the insulation, $k_{i}$ the thermal conductivity of the insulating material, corresponding to an average value for the whole process to fire exposure, and $V_{s}$ the volume of the steel structure per unit length. Increasing $\kappa_{n}$ expresses a decreased insulation capacity.

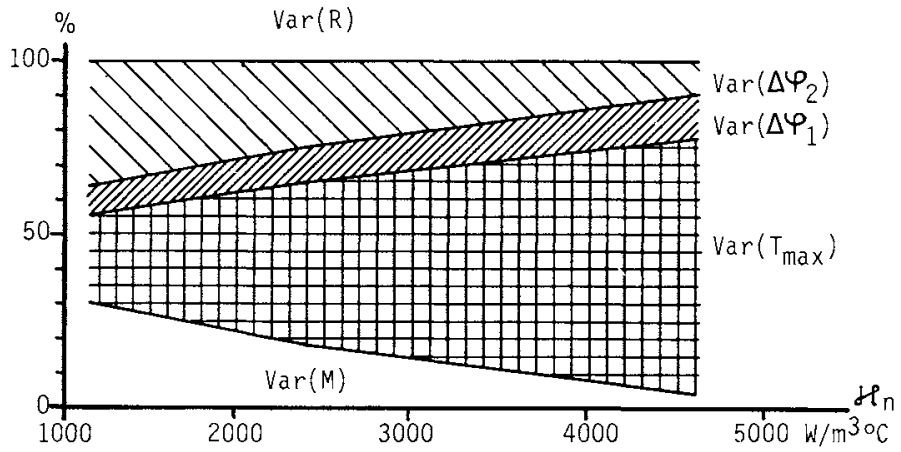

FIGURE 5 . Separation of total variance in load bearing capacity $R$ into component variances as function of insulation parameter $\kappa_{\mathrm{n}}$.

The component variances refer to the stochastic character of the fire load density $q$, the 
uncertainty in the insulation properties $\mathrm{x}$, the uncertainty reflecting the prediction error in the theory of compartment fires and heat transfer from the fire process to the structural member $\Delta \mathrm{T}_{2}$, and a correction term reflecting the difference between a natural fire in a laboratory and under real life service condtions $\Delta \mathrm{T}_{3}$. Analogously, Figure 5 exemplifies the decomposition of the total variance in the load bearing capacity $R$ into component variances as a function of the insulation parameter $\kappa_{n}$. The component variances refer to the variability in the maximum steel temperature $T_{\max }$, variability in material strength $M$, the uncertainty reflecting the prediction error in the strength theory $\Delta \Phi_{1}$, and the uncertainty due to the difference between laboratory tests and in situ fire exposure $\Delta \Phi_{2}$.

A supplementary illustration of results of sensitivity studies regarding structural fire engineering design is shown in Figure 6 [118]. The study reported deals with the sensitivity of the charcoal layer penetration for a fire exposed timber structure as a function of certain material input data in a defined simulation model and the figure gives the influence of varying the thermal conductivity of the charcoal and the rate of surface reaction.
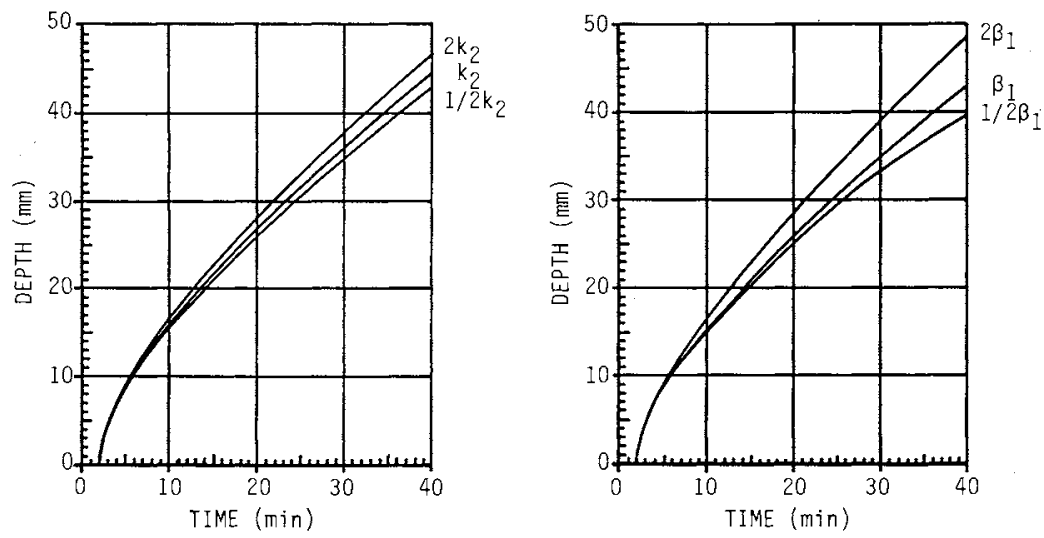

FIGURE 6. Depth of charring as function of time for variable thermal conductivity $k_{2}$ of charcoal and variable rate of surface reaction $\beta_{1}$.

With expanding knowledge on parameter and component uncertainties, the qualifications increase for a structural fire engineering design based on the principles of cost-benefit optimization [1]. Minimizing the total cost for a fully developed or post flashover compartment fire and its expected consequences, then determines the optimum failure probability or target probability

The total cost $C_{\text {tot }}$ can be written as

$$
C_{\text {tot }}=C_{p}+\left[C_{f o}+\Delta C \cdot P(\text { fail/fo })\right] P(\text { fo })
$$

where $C_{p}$ is the cost of the passive fire protection measures, $C_{f o}$ the direct losses due to flashover without failure of the loadbearing structure, $\Delta \mathrm{C}$ the additional expected cost due to failure, $\mathrm{P}(\mathrm{fo})$ the probabilty of flashover, and $\mathrm{P}(\mathrm{fail} / \mathrm{fo})$ the failure probability on the condition of flashover. 
Assume that $\mathrm{x}$ is some passive fire protection parameter - for instance, the thickness of an insulation of a steel structure - which affects the failure probability but not the flashover probability. Minimizing the total $\cos t \mathrm{C}_{\text {tot }}$ then gives the equation

$$
\frac{\delta C_{\text {tox }}}{\delta x}=\frac{\delta C_{p}}{\delta x}+\Delta C \frac{\delta P(f a i l / f o)}{\delta x} P(f o)=0
$$

from which the optimum failure probability $\mathrm{P}(\mathrm{fail} / \mathrm{fo})_{\mathrm{opt}}$ can be determined.

A condition for the described optimization approach is that people can escape safely from the building at fire which requires a design evacuation time which is less than the expected time of failure of the load bearing structure. If a failure leads to both monetary and human life losses, then assessment problems arise which are not yet solved for neither fire design nor normal design.

\section{REFERENCES}

1. CIB W14, "A Conceptual Approach towards a Probability Based Design Guide on Structural Fire Safety", Fire Safety Journal, 6, 1-79, 1983.

2. CIB W14, "Design Guide - Structural Fire Safety", Fire Safety Journal, 9, 77-136, 1986.

3. Anderberg, Y. and Thelandersson, S., Stress and Deformation Characteristics of Concrete at High Temperatures, Lund Institute of Technology, Division of Structural Mechanics and Concrete Construction, Bulletin 54, Lund, 1976.

4. Schneider, U., Ein Beitrag zur Frage des Kriechens und der Relaxation von Beton unter hohen Temperaturen, Institut für Baustoffe, Massivbau und Brandschutz der Technischen Universität Braunschweig, Heft 42, Braunschweig, 1979. - "Concrete at High Temperatures - A General Review", Fire Safety Journal, 13, 55-68, 1988.

5. Khoury, G.A. and Grainger, B.N., "Strain Behaviour of Concrete under Various Temperature-Time Regimes", in 3rd International Workshop on Behaviour of Concrete under Thermal and Hygral Gradients, pp. 165-170, Weimar, 1992.

6. Hadvig, S., Charring of Wood in Building Fires - Practice, Theory, Instrumentation, Measurements, Laboratory of Heating and Air Conditioning, Technical University of Denmark, Copenhagen, 1981.

7. Fredlund, B., A Model for Heat and Mass Transfer in Timber Structures During Fire, Lund Institute of Technology, Department of Fire Safety Engineering, Report LUTVDG/(TVBB-1003), Lund, 1988.

8. White, R.H. and Nordheim, E.V., "Charring Rate of Wood for ASTM E 119 Exposure", Fire Technology, 28:1, 5-30, 1992.

9. Lie, T.T., Fire and Buildings, Applied Science Publishers, London, 1972. 
10. Pettersson, O., Magnusson, S.E. and Thor, J., Fire Engineering Design of Steel Structures, Swedish Institute of Steel Construction, Publication No. 50, Stockholm, 1976 (Swedish Edition 1974).

11. Pettersson, O., Theoretical Design of Fire Exposed Structures, Lund Institute of Technology, Division of Structural Mechanics and Concrete Construction, Bulletin 51, Lund, 1976.

12. Gustaferro, A.H. and Martin, L.D., PCI Design for Fire Resistance of Precast Prestressed Concrete, Prestressed Concrete Institute, PCI, Chicago, 1977.

13. Institution of Structural Engineers, Concrete Society, Design and Detailing of Concrete Structures for Fire Resistance, Interim Guide, The Concrete Society, London, 1978.

14. Barthélémy, B. and Kruppa, J., Résistance au Feu des Structures-Béton, Acier, Bois, Edition Eyrolles, Paris, 1978.

15. Pettersson, O. and Ödeen, K., Fire Engineering Design of Building Structures = Principles, Design Rules, Examples (in Swedish), Liber Publishers, Stockholm, 1978.

16. Harmathy, T.Z., "Design to Cope with Fully Developed Fires", in Design of Buildings for Fire Safety, ASTM Special Technical Publication STP 685, pp. 198-276, Washington, D.C., 1979.

17. AISI, Fire-Safe Structural Steel - A Design Guide, American Iron and Steel Institute (AISI), Ohio, 1979.

18. CSTB (Centre Scientifique et Téchnique du Bâtiment), Méthode de Prévision par le Calcul du Comportement au Feu des Structures en Béton, Document Téchnique Unifié, Paris, 1980.

19. Twilt, L. and Witteveen, J., Fire Resistance of Steel Structures (in Dutch), Staalcentrum Nederland, 1980.

20. Dotreppe, J.C., Modéles Numérique pour le Simulation du Comportement au Feu des Structures en Acier et en Béton Armé, Thèse d'Agrégation de l'Enseignement Supérieur, Université de Liège, 1980.

21. ACI (American Concrete Institute), Guide for Determining the Fire Endurance of Concrete Elements, ACI Committee 216, ACI 216R-81, 1981.

22. Thrane, E.J., Fire Engineering Design of Building Structures (in Norwegian), Tapir forlag, Oslo, 1981.

23. Kordina, K. and Meyer-Ottens, C., Beton-Brandschutz-Handbuch, Beton-Verlag, Düsseldorf, 1981.

24. Pettersson, O, Magnusson, S.E. and Thor, J., Rational Approach to Fire Engineering Design of Steel Buildings, Lund Institute of Technology, Division of Building Fire Safety and Technology, Report LUTVDG/(TVBB-3002), Lund, 1981. 
25. Malhotra, H.L., Design of Fire Resisting Structures, Surrey University Press, London, 1982.

26. CTICM (Centre Téchnique Industrial de la Construction Métallique), "Méthode de Prévision par le Calcul du Comportement au Feu des Structures en Acier", Revue Construction Métallique, $\mathrm{N}^{\circ} \underline{3}$, Paris, 1982.

27. Forsén, N.E., Theoretical Study on the Fire Resistance of Concrete Structures, FCBSINTEF, Report STF 65 A82062, Trondheim, 1982.

28. ECCS (European Convention for Constructional Steelwork), Calculation of the Fire Resistance of Load Bearing Elements and Structural Assemblies Exposed to the Standard Fire, European Recommendations for the Fire Safety of Steel Structures, Elsevier, Amsterdam-Oxford-New York, 1983.

29. Brozzetti, J., Law, M., Pettersson, O. and Witteveen, J., "Safety Concept and Design for Fire Resistance of Steel Structures", IABSE Surveys, S-22/83, Zürich, 1983.

30. ECCS (European Convention for Constructional Steelwork), Design Manual on the European Recommendations for the Fire Safety of Steel Structures, ECCS, Publication No. 35, Brussels, 1985.

31. Jönsson, R. and Pettersson, O., Timber Structures and Fire, Swedish Council for Building Research, Document D3:1985, Stockholm, 1985 (Swedish Edition 1983).

32. Kirby, B.R., "Recent Developments and Applications in Structural Fire Engineering Design - A Review", Fire Safety Journal, 11, 141-179, 1986.

33. Hass, R., Meyer-Ottens, C. and Quast, U., Verbundbau-Brandschutz-Handbuch, Verlag W. Ernst \& Sohn, Berlin, 1989.

34. Carling, O., Fire Engineering Design of Timber Structures (in Swedish), Swedish Institute for Wood Technology Research, Report I 9004018, Stockholm, 1990.

35. CEB (Comité Euro-International du Béton), Fire Design of Concrete Structures, Bulletin d'Information $\mathrm{N}^{\mathbf{0}}$ 208, Lausanne, 1991.

36. Anderberg, Y. and Pettersson, O. Fire Engineering Design of Concrete Structures (in Swedish), Swedish Council for Building Research, T13:1992, Stockholm, 1992.

37. International Iron and Steel Institute, Fire Engineering Design for Steel Structures: State of the Art, Brussels, 1993.

38. Hass, R., Meyer-Ottens, C. and Richter, E., Stahlbau-Brandschutz-Handbuch, Verlag W. Ernst \& Sohn, Berlin, 1993.

39. Kordina, K., Meyer-Ottens, C. and Scheer, C., Holz-Brandschutz-Handbuch, Verlag W. Ernst \& Sohn, Berlin, 1994 (First Edition 1983).

40. Magnusson, S.E and Pettersson, O., "Functional Approaches - An Outline", in Fire 
Safety in Buildings: Needs and Criteria, CIB Symposium, held in Amsterdam, 2-3 June, 1977, Publication 48, CIB Proceedings, 120-145, Amsterdam, 1977.

41. Magnusson, S.E. and Pettersson, O, "Rational Design Methodology for Fire Exposed Load Bearing Structures", Fire Safety Journal, $\underline{3}$, 227-241, 1980/81.

42. Pettersson, O. and Jönsson, R., Reliability Based Design of Fire Exposed Timber Structures - State of Art and Summary Design Guide, Lund Institute of Science and Technology, Department of Fire Safety Engineering, Report LUTVDG/(TVBB-3040), Lund, 1988.

43. Schneider, U., Bub, H. and Kersken-Bradley, M., "Structural Fire Protection Levels for Industrial Buildings", 1980 Fall Convention, American Concrete Institute, San Juan, Porto Rico, 1980.

44. Hosser, D. and Schneider, U., Sicherheitskonzept für brandschutztechnische Nachweise von Stahlbetonbauteilen nach der Wärmebilanztheorie, Institut für Bautechnik, Berlin, 1980.

45. Pettersson, O., "Reliability Based Design of Fire Exposed Concrete Structures", in Contemporary European Concrete Research, 143-169, Stockholm, 1981.

46. CEN/TC250/SC1, pr ENV 1991-2-2, EUROCODE 1: Basis of Design and Actions on Structures, Part 2.2: Actions on Structures Exposed to Fire, April, 1993.

47. CEN/TC250/SC2, pr ENV 1992-1-2, EUROCODE 2: Design of Concrete Structures, Part 1-2: Structural Fire Design, October, 1993.

48. CEN/TC250/SC3, pr ENV 1993-1-2, EUROCODE 3: Design of Steel Structures, Part 1-2: Structural Fire Design, August, 1993.

49. CEN/TC250/SC4, pr ENV 1994-1-2, EUROCODE 4: Design of Composite Steel and Concrete Structures, Part 1-2: Structural Fire Design, November, 1993.

50. CEN/TC250/SC5, pr ENV 1995-1-2, EUROCODE 5: Design of Timber Structures, Part 1-2: General Rules. Supplementary Rules for Structural Fire Design, October, 1993.

51. Harmathy, T.Z. and Mehaffey, J.R., "Post-flashover Compartment Fires: A Review.", Fire and Materials, 7 , 49-61, 1983.

52. Kawagoe, K. and Sekine, T., Estimation of Fire Temperature-Time Curve in Rooms, Building Research Institute, Occasional Report No. 11, Tokyo, 1965. - Kawagoe, K., Estimation of Fire Temperature-Time Curve in Rooms, Building Research Institute, Research Paper No. 29, Tokyo, 1967.

53. Ödeen, K., Theoretical Study of Fire Characteristics in Enclosed Spaces, Royal Institute of Technology, Division of Building Construction, Bulletin 19, Stockholm, 1963.

54. Magnusson, S.E. and Thelandersson, S., Temperature-Time Curves for the Complete Process of Fire Development - A Theoretical Study of Wood Fuel Fires in Enclosed 
Spaces, Acta Polytechnica Scandinavica, Ci 65, Stockholm, 1970.

55. Harmathy, T.Z., "A New Look at Compartment Fires", Part I, Fire Technology, 8 , 196217, 1972, Part II, Fire Technology, 8 , 326-351, 1972.

56. Babrauskas, V. and Williamson, R.B., Post-flashover Compartment Fires, University of California, Fire Research Group, Report No. UCB FRG 75-1, Berkeley, 1975. - "Postflashover Compartment Fires: Basis of a Theoretical Model", Fire and Materials, 2, 39$53,1978$.

57. Thomas, P.H., "Some Problem Aspects of Fully Developed Room Fires", in Fire Standards and Safety, ASTM Special Technical Publication STP 614, pp. 112-130, Washington, D.C., 1977.

58. Babrauskas, V., COMPF2 - A Program for Calculating Postflashover Fire Temperatures, National Bureau of Standards, Technical Note 991, Washington, D.C., 1979.

59. Schneider, U. and Haksever, A., Wärmebilanzberechnungen für Brandräume mit underschiedlichen Randbedingungen. Technische Universität Braunschweig, Institut für Baustoffe, Massivbau und Brandschutz, Braunschweig, 1980.

60. Babrauskas, V., "A Closed-form Approximation for Postflashover Compartment Fire Temperatures", Fire Safety Journal, $\underline{4}$, 63-73, 1981.

61. Nakaya, I. and Akita, K., "A Simulation Model for Compartment Fires", Fire Safety Journal, $\underline{5}, 157-165,1983$.

62. Magnusson, S.E. and Jönsson, R., Calculation of Gastemperature-Time Curves Using Recent Research Development, Lund Institute of Technology, Division of Building Fire Safety and Technology, Lund, 1985.

63. Wickström, U., "Application of the Standard Fire Curve for Expressing Natural Fires for Design Purposes", in Fire Safety: Science and Engineering, ASTM Special Technical Publication STP 882, pp. 145-159, Philadelphia, 1985.

64. Harmathy, T.Z., "Postflashover Fires - An Overview of the Research at the National Research Council of Canada", Fire Technology, 22, 210-233, 1986.

65. Birk, D.M., An Introduction to Mathematical Fire Modeling, Technomic Publ. Co., Lancester-Basel, 1991.

66. National Swedish Board of Physical Planning and Building, Fire Engineering Design (in Swedish), Comments on Swedish Building Code (SBN) No. 1976:1, Stockholm, 1976.

67. Law, M., Design for Fire Safety of Bare Exterior Structural Steel. 1. Theory and Validation. 2. State of the Art, Ove Arup and Partners, London, 1977.

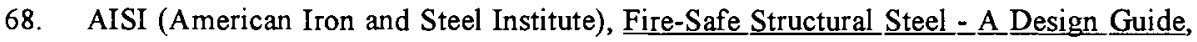
Washington, D.C., 1979. 
70. Kumar, S. and Cox, G., "Radiation and Surface Roughness Effects in the Numerical Modelling of Enclosure Fires", in Fire Safety Science, Proceedings of the Second International Symposium, pp. 851-860, Hemisphere Publishing Corp., New YorkWashington-Philadelphia-London, 1989.

71. Fredlund, B., "Modelling of Heat and Mass Transfer in Wood Structures During Fire", Fire Safety Journal, 20, 39-69, 1993.

72. Harada, K. and Terai, T., "Heat and Mass Transfer in an Intensely Heated Mortar Wall", in Fire Safety Science. Proceedings of the Third International Symposium, pp. 781-790, Elsevier Applied Science, London-New York, 1991.

73. Ehm, H., Ein Beitrag zur rechnerischen Bemessung von brandbeanspruchten balkartigen Stahlbetonbauteilen, Technische Universität Braunschweig, Dissertation, Braunschweig, 1967.

74. Odeen, $\mathbf{K}$, Fire Resistance of Concrete Double T Units, Acta Polytechnica Scandinavica, Ci 48, Stockholm, 1968.

75. Kordina, K., Schneider, U., Haksever, A. and Klingsch, W., Zur Berechnung von Stahlbetonkonstruktionen im Brandfall, Technische Universität Braunschweig, Institut für Baustoffe, Massivbau und Brandschutz, Braunschweig, 1975.

76. Rudolphi, R and Müller, T., ALGOL - Computerprogramm zur Berechnung zweidimensionaler instationärer Temperaturenverteilungen mit Anwendungen aus dem Brand- und Wärmeschutz, BAM-Forschungsbericht Nr 74, Berlin, 1980.

77. Becker, J., Bizri, H. and Bresler, B., FIRES-T, A Computer Program for the Fire Response of Structures - Thermal, University of California, Fire Research Group, Report No. UCB FRG 74-1, Berkeley, 1974.

78. Iding, R., Bresler, B., and Nizzamuddin, Z., FIRES-T3, A Computer Program for the Fire Response of Structures - Thermal (Three Dimensional Version), University of California, Fire Research Group, Report No. UCB FRG 77-15, Berkeley, 1977.

79. Wickström U., TASEF-2, A Computer Program for Temperature Analysis of Structures Exposed to Fire, Lund Institute of Technology, Department of Structural Mechanics, Report No. 79-2, Lund, 1979.

80. Sterner, E. and Wickström, U., TASEF - Temperature Analysis of Structures Exposed to Fire - User's Manual, Swedish National Testing Institute, Fire Technology, SP Report 1990:5, Borås, 1990.

81. Anderberg, Y. and Paulsson, M., TEMPCALC, A Computer Program for Temperature Analysis of Structures Exposed to Heat, Institute of Fire Safety Design, Lund, 1985. TEMPCALC III, A Computer Program for 3-Dimensional Temperature Analysis of Structures Exposed to Heat, Fire Safety Design, Lund, 1991. 
82. Anderberg, Y., SUPER-TEMPCALC, A Commercial and Userfriendly Computer Program with Automatic FEM-Generation for Temperature Analysis of Structures Exposed to Heat, Fire Safety Design, Lund, 1991.

83. RILEM, Anderberg, Y. (ed.), Properties of Materials at High Temperatures - Steel, Lund Institute of Technology, Division of Building Fire Safety and Technology, Report LUTVDG/(TVBB-3008), Lund, 1983.

84. Dorn, E.J., "Some Fundamental Experiments on High Temperature Creep", in Creep and

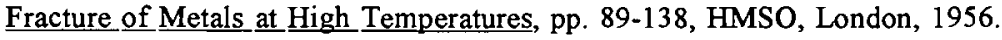

85. Thor, J., Deformations and Critical Loads of Steel Beams Under Fire Exposure Conditions, Lund Institute of Technology, Division of Structural Mechanics and Concrete Construction, Bulletin 35, Lund, 1973.

86. Harmathy, T.Z., "Creep Deflection of Metal Beams in Transient Heating Processes, with Particular Reference to Fire", Canadian Journal of Civil Engineering, 3:2, 219-228, 1976.

87. Furumura, F. and Shinohara, Y., Inelastic Behaviour of Protected Steel Beams and Frames in Fire, Research Laboratory of Engineering Materials, Tokyo, 1978.

88. Beyer, R. and Hartmann, B., "Eine Untersuchung des Lastfalles Brand beim Stahlrahmen", in Kolloquim für Finite Elemente in der Baupraxis, Hannover, 1978.

89. Iding, R.H. and Bresler, B., Effect of Fire Exposure on Steel Frame Buildings (Computer Model FASBUS II), Final Report WJE 78124, Wiss, Janney, Elstner and Associates, Inc., 1981.

90. Forsén, N.E., STEELFIRE - Finite Element Program for Non-Linear Analysis of Steel Frames Exposed to Fire, User's Manual, Multiconsult A/S, Oslo, 1983.

91. Peterson, A., Finite Element Analysis of Structures at High Temperatures, with Special Application to Plane Steel Beams and Frames, Lund Institute of Technology, Division of Structural Mechanics, Report TVSM-1001, Lund, 1984.

92. Quast, U., Hass, R. and Rudolph, K., STABA-F; A Computer Program for the Determination of Load Bearing and Deformation Behaviour of Uni-Axial Structural Elements under Fire Action, Technische Universität Braunschweig, Institut für Baustoffe, Massivbau und Brandschutz, Braunschweig, 1984.

93. CEC Research 7210-SA/502-REFAO/CAFIR, Computer Assisted Analysis of the Fire Resistance of Steel and Composite Steel-Concrete Structures (Computer Program CEFICOSS), Technical Reports RT1-6, 1982/85.

94. Saito, H., Uesugi, H., Yamaguchi, M. and Kodaira, A., "Thermal Stress and Deformation of High Rise Buildings in Fire", in Fire Safety Science, Proceedings of the Second International Symposium, pp. 719-728, Hemisphere Publishing Corp., New YorkWashington-Philadelphia-London, 1989. 
95. Migita, K., Okabe, T., Furumura, F., Ave, T. and Kim, W.J., "Elasto-Plastic Creep Thermal Deformation Behavior of Multi-Storey Steel Frames Designed by the Plastic Method", in Fire Safety Science Proceedings of the Second International Symposium, pp. 739-748, Hemisphere Publishing Corp., New York-Washington-PhiladelphiaLondon, 1989.

96. Eberg, E., Amdahl, J., Holmås, T. and Hekkelstrand, B., Integrated Analysis of Offshore Structures Subjected to Fire, SINTEF, Report STF 70 F92157, Trondheim, 1992.

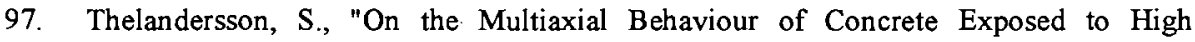
Temperature", Nuclear Engineering and Design. 75:2, 271-282, 1983.

98. RILEM, Schneider, U. (ed.), Properties of Materials at High Temperatures -Concrete, Gesamthochschule Kassel, Department of Civil Engineering, Kassel, 1985.

99. Becker, J.M. and Bresler, B., FIRES-RC, A Computer Program for the Fire Response of Structures - Reinforced Concrete Frames, University of California, Fire Research Group, Report No. UCB FRG 74-3, Berkeley, 1974.

100. Bresler, B., Response of Concrete Frames to Fire. - Bresler, B. et al, Limit State Behaviour of Reinforced Concrete Frames in Fire Environments, University of California, Fire Research Group, Report No. UCB FRG 76-12, Berkeley, 1976.

101. Anderberg, Y., Fire Exposed Hyperstatic Concrete Structures - An Experimental and Theoretical Study, Lund Institute of Technology, Division of Structural Mechanics and Concrete Construction, Bulletin 55, Lund, 1976.

102. Haksever, A., Zur Frage des Trag- und Verformungsverhaltens ebener Stahlbetonrahmen im Brandfall, Institut für Baustoffkunde und Stahlbetonbau der Technischen Universität Braunschweig, Heft 35, Braunschweig, 1977.

103. Klingsch, W. and Wittbecker, F.W., "Structural Fire Engineering of Complex Frames by Means of Micro-Computer Application", in Fire Safety Science, Proceedings of the Second International Symposium, pp. 729-738, Hemisphere Publishing Corp., New York-Washington-Philadelphia-London, 1989.

104. Morita, T., Wakamatsu, T., Uesugi, H. and Saito, H., "Analyses of Composite Beams and Frames at Elevated Temperature", in Fire Safety Science, Proceedings of the Third International Symposium, pp. 761-770, Elsevier Applied Science, London-New York, 1991.

105. Nizzamuddin, Z., Thermal and Structural Analysis of Reinforced Concrete Slabs in Fire Environments, Thesis, University of California, Berkeley, 1976. - Nizzamuddin, Z. and Bresler, B., "Fire Response of Concrete Slabs", ASCE Proceedings, Journal of Structural Division, 105:ST8, 1979.

106. Hertz, K., Design of Fire Exposed Concrete Structures, Report No. 160. - Stress Distribution Factors, Technical University of Denmark, Institute of Building Design, Report No. 158, Lyngby, 1981. 
107. Meyer-Ottens, C., Zur Frage der Abplatzungen an Betonbauteilen aus Normalbeton bei Brandbeanspruchung, Dissertation, Technische Universität, Braunschweig, 1972.

108. Zhukov, V.V., "Reasons of Explosive Spalling of Concrete by Fire" (translation from Russian), Beton i Zhelezobeton, 3, 1976.

109. Harmathy, T.Z., "Effect of Moisture on the Fire Endurance of Building Elements", in Moisture in Materials in Relation to Fire Tests, ASTM Special Technical Publication STP 385, pp. 74-94, Chicago, 1964.

110. Bennet, J., Claesson, J. and Thelandersson, S., Calculation of Temperature, Moisture, and Pressure Distributions in Concrete Exposed to Fire, Lund Institute of Technology, Department of Mathematical Physics and Division of Structural Mechanics, Lund, 1976.

111. Grauers, K., Cederwall, K. and Gylltoft, K., Anchorage and Shear in Concrete Structures Exposed to Fire - A Literature Review, Swedish National Testing and Research Institute, Fire Technology, SP Report 1994:02, Borås, 1994.

112. Gerhards, C.C., "Effects of Moisture Content and Temperature on the Mechanical Properties: An Analysis of Immediate Effects", Wood and Fiber, 1, 4-36, 1982.

113. Schaffer, E.L., Elevated Temperature Effect on the Longitudinal Mechanical Properties of Wood, Thesis, University of Wisconsin, Engineering Mechanics, Wisconsin, 1971.

114. Fredlund, B., Structural Design of Fire Exposed Rectangular Laminated Wood Beams with Respect to Lateral Buckling, Lund Institute of Technology, Department of Structural Mechanics, Report No. 79-5, Lund, 1979.

115. ASTM, Standard Guide for Evaluating the Predictive Capability of Fire Models, ASTM Designation: E 1355-92, New York, 1992.

116. ASTM, Standard Guide for Documenting Computer Software for Fire Models, ASTM Designation: E 1472-92, New York, 1992.

117. Magnusson, S.E., Probabilistic Analysis of Fire Exposed Steel Structures, Lund Institute of Technology, Division of Structural Mechanics and Concrete Construction, Bulletin 27, Lund, 1974.

118. Fredlund, B., A Computer Program for the Analysis of Timber Structures Exposed to Fire, Lund Institute of Technology, Division of Building Fire Safety and Technology, Report LUTVDG/(TVBB-3020), Lund, 1985. 